Torkil Berge, psykologspesialist, Voksenpsykiatrisk avdeling Vinderen, Diakonhjemmet Sykehus.
Elin Fjerstad, psykologspesialist, Prosjekt klinisk helsepsykologi, revmatologisk avd. Diakonhjemmet Sykehus.

\section{Sprøyteskrekk kan kureres}

\author{
Angst for sprøyter har mange uheldige konsekvenser, men kognitiv \\ atferdsterapi kan hjelpe.
}

B iologiske medisiner brukes i dag i behandling av revmatiske inflammatoriske sykdommer. Det er medisiner som pasientene setter selv i form av injeksjoner eller som de får intravenøst. Også pasienter med multippel sklerose og diabetes har behov for å ta sprøyter regelmessig. Noen vegrer seg for å ta imot slik behandling fordi de er redde for sprøyter. Andre tar imot selv om det innebærer en stor psykisk påkjenning, og får dermed en vedvarende stressbelastning som pasienter med kroniske sykdommer strengt tatt ikke har helse til (1). Når sykdomsaktivitet ikke behandles, fører det til skade på ledd og indre organer. Angst for sprøyter og for å se blod fører generelt til at mange personer lar være å oppsøke lege, tannlege og sykehus, selv ved akutte behov. De kan også unnlate å ta nødvendige vaksiner, for eksempel i forbindelse med utenlandsreiser, noe som fører til økt risiko for spredning av smitte. Angst for å ta sprøyter har altså mange uheldige helsemessige konsekvenser. Vi vil beskrive bruk av en kognitiv atferdsterapeutisk behandling av blod-, skade- og injeksjonsfobi, i det følgende kalt sprøytefobi, hos en kvinne med Bechte-

\section{Hovedbudskap}

Mange pasienter med kronisk sykdom vegrer seg for injeksjoner på grunn av sprøytefobi. Gjennom systematisk angsttrening kan pasienten lære å foreta selvinjeksjoner. Det er viktig at helsepersonell har kunnskap om og kan tilby slik behandling.

\section{Søkeord}

Les mer og finn litteraturhenvisninger på våre nettsider. ) Angst > Psykologi | Veiledning | Terap rews sykdom, og gi råd om tilrettelegging ved sprøytetaking.

\section{Spesifikk fobi}

Fobi er en ekstrem frykt som ikke står i forhold til situasjonen, og som er forbundet med et sterkt ønske om å unngå eller flykte fra den. Spesifikke fobier er begrenset til bestemte objekter eller situasjoner, for eksempel insekter, hunder, høyder og lukkete rom, og altså også sprøyter og det å se blod. vil oppleve, ettersom sterk angst i seg selv er svært opprivende og ubehagelig. Dessuten kan de være redde for å besvime, miste kontrollen eller gjøre noe som er pinlig og flaut når de rammes av redsel. Ved sprøytefobi er mange engstelige for at de skal føle sterk avsky eller frykter at de skal kaste opp.

Det mest effektive for å redusere fobisk angst er å utsette seg for den på en planlagt og systematisk måte. Dette kalles eksponeringstrening. Målet er å venne seg til situasjonen og til kroppsreaksjoner man frykter fordi man forbinder dem med panikk. Det er i dag konsensus om at eksponering er den beste behandlingstilnærmingen for spesifikke fobier, og at resultatene er meget gode for et overveiende flertall av dem som fullfører slik behandling (2). En metaanalyse dokumenterer gode resultater også ved angsttrening som selvhjelp, gjerne med utgangspunkt i skriftlig selvhjelpsmateriell (3). Berge og Repål (4) og Mohr (5) beskriver opplegg for veiledet selvhjelp.

\section{Utbredt problem}

Om lag 10 prosent av pasienter i medisinsk behandling rapporterer om angst og bekymring for å ta sprøyter. For noen blir angsten så sterk at den kan betegnes som en fobi; i en amerikansk befolkningsstudie gjaldt det 3,5 prosent (6). I en studie av 1385 attenårige elever ved videregående I tillegg frykter mange selve panikken de vet de skoler i Hordaland, rapporterte 17 prosent og 15 prosent om angst for sprøyter ved henholdsvis tannlege- og legekonsultasjon (7). I alt 6,7 prosent fortalte at de unnlot å gå til tannlege og 5,2 prosent til lege på grunn av dette. Ifølge Mohr et al. (8) er det data som tyder på at angst for sprøyter er enda mer hyppig ved selvinjeksjon, som er aktuelt ved revmatisk sykdom, diabetes og multippel sklerose. Mange vegrer seg derfor for å foreta injeksjoner selv.

\section{Traumer}

En rekke personer med sprøytefobi forteller at de har hatt traumatiske opplevelser knyttet til sprøyter tidligere i livet (9). Man kan også ha lært slik frykt på en indirekte måte ved å se at andre får panikk i situasjonen eller ved at man har blitt fortalt at det er farlig og smertefullt: Pass deg for sprøyten! Dessuten er det en større arvelighet ved sprøyte- og blodfobi enn for andre fobier (10). Uansett hvordan man har utviklet fobien, vil to forhold bidra til at problemene opprettholdes: Det ene er å unngå eller flykte fra det man er redd for, det andre er tenkemåter som bidrar til økt angst i situasjonen. Unngåelse kan være å unnvike de fobiske situasjonene eller å unngå dem mentalt, for eksempel ved å forestille seg at man er et annet sted. Trygghetssøkende strategier eller sikringsatferd er en form for unngåelse som bidrar til å holde oppmerksomheten rettet mot det man frykter vil skje, og dermed opprettholde fobisk angst. Eksempler er å holde konstant øye med sprøyten, puste på bestemte måter og utføre langsomme bevegelser. Den andre faktoren som opprettholder fobier er katastrofetanker som: «Sprøytespissen vil treffe et bein og brekke inne i armen min», «nå besvimer jeg» eller «jeg kommer til å bli skadet». Slike negative tanker vil ofte være automatiserte, det vil si selvdrevne og ikke bevisste. I kognitiv 


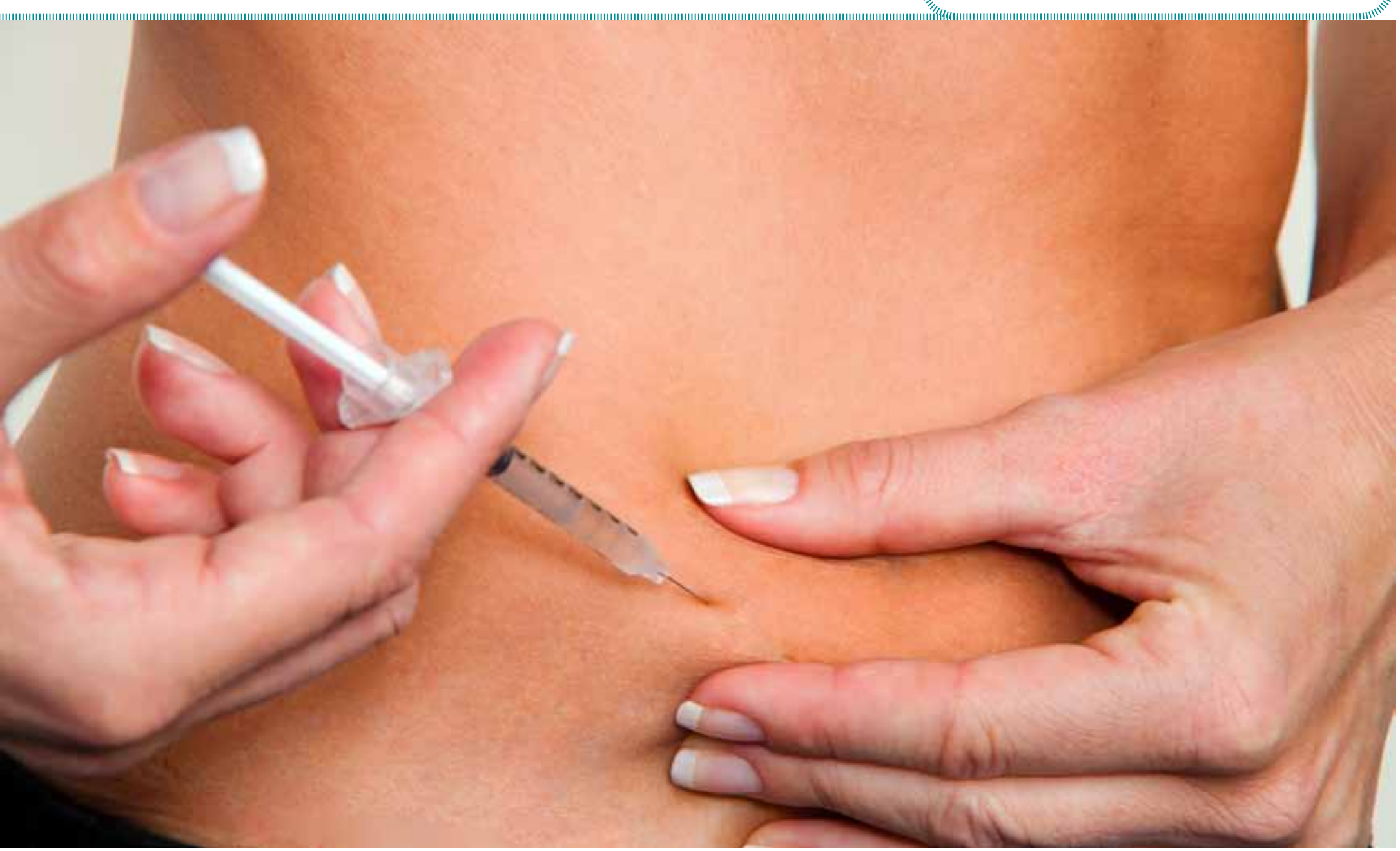

ANGST FOR SPRøYTER: Mange mennesker med kroniske sykdommer som gjør at de må sette sprøyter på seg selv, sliter med alvorlig sprøyteskrekk. Illustrasjonsfoto: Colourbox.

terapi vil man under eksponeringen søke å få dem opp i lyset gjennom sokratiske spørsmål, slik at de kan bli vurdert og testet ut (11).

\section{Svimmelhet}

I motsetning til alle andre fobier er fobi for injeksjoner og blod forbundet med svimmelhet og økt risiko for å besvime. Over 75 prosent kan oppleve en paradoksal fysiologisk reaksjon ved synet av sprøyter og blod. Personen får da først den vanlige reaksjonen ved angst: sterk aktivering i det sympatiske nervesystemet, med økt hjertefrekvens og blodtrykk, men opplever så en deaktivering med raskt fall i hjertefrekvens og lavt blodtrykk. For dem som har erfart å besvime, kan frykten for å gjenoppleve dette forsterke sprøytefobien. Risikoen for å besvime øker hos dem som i tillegg til angst reagerer med sterk avsky for sprøyter og blod, der nettopp kombinasjonen av frykt og avsky gir mer svimmelhet (12). Svimmelheten forsterkes ytterligere fordi mange hyperventilerer i den fobiske situasjonen; de puster mer enn det kroppen har bruk for (13). For å redusere svimmelhet under angsttreningen, lærer pasienten en egen kroppsspenningsteknikk, slik pasienten Wenche gjorde i følgende kliniske eksempel.

\section{Wenches historie}

Behandlingen vi vil beskrive går over åtte sesjoner à halvannen time. Wenche har treningsoppgaver mellom hver time, som blir fulgt opp gjennom kortvarige telefonsamtaler. Slik forteller Wenche om bakgrunnen for sin sterke angst: «Det hele startet da jeg var fire år gammel og skulle ta blodprøver: Mamma er med meg inn på legekontoret. Så kommer to hvitkledde personer, store som monstre. Den ene holder meg fast og den andre stikker. Det er alt jeg husker. Siden har jeg hatt panikk for sprøyter. Etter at jeg fikk Bechterews sykdom og må ta Humira annenhver uke, og blodprøver helst hver måned, har sprøyteskrekken blitt en enorm belastning for meg. Jeg gruer meg i dagevis og utsetter sprøyten så lenge som mulig. Konsekvensene er at jeg blir mer stiv og får mer vondt. Jeg makter ikke å ta sprøyter selv, mannen min må gjøre det, og blodprøver som jeg bør ta hver måned, tar jeg kanskje hver tredje måned. Det er risikabelt fordi blodverdiene bør følges oftere. Jeg skammer meg over ikke å kunne håndtere dette bedre. Jeg er ellers ganske tøff av meg. Det er et problem som svekker selvfølelsen min, og som jeg nødig snakker med andre om.»

\section{Katastrofetanker}

I første time stiller vi Wenche en rekke spørsmål for å kartlegge tanker, følelser, kroppsreaksjoner og handlingsmønstre i den fobiske situasjonen. Katastrofetanker som kan dukke opp, handler om at hun ikke har kontroll og mulighet til å påvirke det som skjer, at hun vil miste kontrollen over seg selv, og at hun vil bli skadet. Et skremmende mentalt bilde som ofte melder seg, er at hun får sprøytespissen inn i øyet. Bare det å snakke om dette vekker sterk angst. Likevel får vi tillatelse til å utforske Wenches opplevelse ved å stille systematiske spørsmål om hva det aller verste som kan skje, er - ut fra hennes tenkning i selve situasjonen. Det viser seg at uavhengig av om hun ellers kan ha tillit til den som setter sprøyten, vil hun der og da ha en intens opplevelse av fare og av at personen plutselig kan komme til å hugge løs på henne med sprøyten. Selv om hun vet at risikoen for at personen stikker feil eller glipper taket i sprøyten er lav, sier angsten det motsatte. Wenche får også katastrofetanker om at hun selv kan gjøre noe ukontrollert som forsterker risikoen. Dessuten blir hun fort blek og svimmel, med en følelse av å kunne besvime hvert øyeblikk. Det å miste bevisstheten er intenst skremmende, fordi det vil gjøre henne totalt forsvarsløs. I tillegg kommer en sterk følelse av å være liten, svak og dum og en rekke tanker preget av selvforakt og skam.

\section{Angsttrening}

Wenche får informasjon om de vanligste kroppslige endringene under angst, og den fysiologiske bakgrunnen disse har. Det viktigste budskapet 
er at selv om sterk angst er ubehagelig, er den ikke farlig. Kroppsreaksjonene er tvert om rettet mot å beskytte mot farer. De skal gjøre oss raskere og sterkere når vi flykter eller forsvarer oss. Mye av kroppens alarmsystem styres av amygdala, et slags angstsenter som har betydning for følelsesmessige reaksjoner og som ligger i det limbiske systemet i den gamle pattedyrhjernen (14). En viktig oppgave for dette senteret er lynraskt å gripe fatt i sanseinformasjon som varsler en trussel, for eksempel en plutselig, brå bevegelse av en spiss gjenstand, før synsinntrykket har nådd fram til delene av hjernen som har med den bevisste opplevelsen å gjøre. Derfor reagerer man ofte følelsesmessig med hjertebank og økt blodtrykk før man helt oppfatter hva som skjer. Denne innledende fryktreaksjonen kan ofte ikke kontrolleres. Alle som har fobisk angst, og dermed en «skvetten» amygdala i slike situasjoner, kan ikke la være å angst, som avstanden til sprøyten, hvor nært vi sitter henne, hvor på sprøyten hun tar og hvor på kroppen den injiseres. Vi lager en foreløpig framdriftsplan for treningen, der de første skrittene er at hun skal holde i sprøyten, og gradvis lære å håndtere den, for så å fjerne plasthetten. Hun skal også trene på å la en av oss sitte innenfor en armlengdes avstand til sprøyten, samtidig som vi etter hvert gjør bevegelser, som å løfte armen mot henne eller reise oss opp, noe som er intenst skremmende for Wenche. Ektefellen assisterer som medhjelper under enkelte hjemmeoppgaver. Han er med i tre timer for å få kunnskap om hva han skal gjøre, som at det er Wenche som må ha regien, betydningen av forutsigbarhet under treningen, samt å bidra med oppmuntring og gi belønning etter treningsøktene (4, s. 237-241 for en «stillingsinstruks» for medhjelpere).

Eksponeringen utformes som atferdseksperi-

\section{«Fobi for injeksjoner og blod er forbundet med svimmelhet og økt risiko for å besvime.»}

reagere med frykt. Men hvis Wenche overvinner sin angst for frykten, ikke flykter fra den og blir værende i den fobiske situasjonen, kan hun gjenvinne kontroll over bremsene. Slik kan hun også, gjennom erfaringsbasert læring, nå fram til amygdala og angstsenteret i hjernen med budskapet om at situasjonen ikke er farlig. Vi understreker at Wenche vil ha regi på hvordan treningen gjennomføres, og avtaler et stoppsignal som gir Wenche full kontroll. Vi kommer aldri til å foreta noe som hun ikke er varslet om på forhånd. Angst handler om en følelse av ikke å ha kontroll og av ikke å kunne forutsi hva som skjer. Derfor skal Wenche sikres opplevelse av kontroll og forutsigbarhet: «I dette arbeidet er det du som er sjefen. Vi skal sitte her helt rolig, og vi skal snakke sammen mens du trener.» Angsttrening krever motivasjon, viljekraft og mot. Vi legger ikke skjul på at treningen vil bli ubehagelig for Wenche. Den innebærer jo at hun skal oppsøke situasjoner som hun er redd for. Nøkkelen til suksess ligger i en systematisk framgangsmåte.

\section{Gradering av angst}

Wenche lærer å gradere angsten under treningen på en skala fra 0 til 100, hvor 0 er fravær av angst og hvor 100 er full panikk, mens 25 er mild angst og 75 er alvorlig angst. Så går vi igjennom hvordan ulike faktorer kan føre til økt menter der Wenche får undersøkt gyldigheten av sine negative forestillinger. Før hver oppgave spør vi om hva hun tror vil skje, og så testes dette ut: «Hvordan tror du at du vil reagere dersom du løfter sprøyten inn mot hånden din, men uten å berøre den?» Wenche gjennomfører hver oppgave til angsten er redusert til minimum det halve på hennes subjektive angstskala fra 0 til 100. Dette er en «veien blir til mens man går»-strategi, der erfaringene med én oppgave danner utgangspunkt for valg av neste oppgave.

\section{Ekko fra fortiden}

Vi formidler til Wenche at noe av angsten hun opplever under treningen synes å være forbundet med den intense skrekken hun følte da hun fire år gammel ble holdt fast av to voksne som tok blodprøve. Overveldende opplevelser kan lagres permanent i hjernen, frosset i tid, og dukke opp som ekko fra fortiden i tilsvarende situasjoner. Dette er en normal del av menneskets naturlige varslingssystem. Vi sier at når Wenche føler seg liten, er det kanskje nettopp når hun kommer i kontakt med disse minnene. Det positive her er at dette gir «store Wenche» en god mulighet til å formidle trøst og omsorg til «lille Wenche». Vi spør henne om hva ektefellen ville ha sagt og gjort i en tenkt situasjon der han var til stede da det skjedde, og også hva hun selv som mor ville formidlet til sine egne barn i en slik situasjon. Wenche får her mer kontakt med sin egenomsorg og selvmedfølelse, og skamfølelsen svekkes gradvis.

\section{Trening}

«Fobi er som en brannvarsler», formidler vi til Wenche. «Alarmen går når det blir varmt, selv om det ikke brenner. Kroppen oppfatter at det er fare på ferde. Du handler først og tenker etterpå, det dreier seg om instinkter. Du er altså ikke pysete. Du har bare instinktene i behold.» Wenche blir stiv av skrekk når hun som i dagens øvelse til slutt får lagt fingeren på sprøyten, i den bakerste enden, så langt bort fra nålen hun kan komme. Poenget er å holde hånden der og ikke trekke den til seg. «Hvor mye angst har du nå på en skala fra 0 til 100?» «Omtrent 85», stotrer Wenche fram. «Det er bra, dette er god trening», svarer vi. Gradvis avtar angsten, fra 85 til 30. Da er det tid for neste oppgave: Å bevege fingeren lenger oppover mot lokket over nålen. Hjertet hamrer. Wenche prøver å puste dypt, men luften vil bare ned i øverste del av lungene: «Tenk om jeg besvimer!» Igjen stiger angsten kraftig, før den stabiliserer seg på et toppunkt og går gradvis nedover. Wenche liker seg ikke, men sitter rolig, og pulsen går nesten normalt. Det hadde hun ikke trodd var mulig.

Underveis i treningen er Wenche ofte redd for å besvime. En måte å forebygge besvimelse på er en metode som øker blodtrykket (9). Vi instruerer Wenche i å oppføre seg som en kroppsbygger som viser fram muskelmassen sin ved å spenne de store muskelgruppene i bryst, overarmer og bein så mye som hun kan i 15-20 sekunder, og så sitte som normalt, men uten å slappe av i 30 sekunder, før hun starter med nye perioder med muskelspenning. Dette trener hun på flere ganger daglig, samtidig som hun lærer seg å kjenne de første tegnene på redusert blodtrykk. Denne øvelsen gir Wenche et hjelpemiddel mot svimmelheten og en økt opplevelse av kontroll.

Hele tiden kartlegger vi Wenches trygghetssøkende strategier, for eksempel når hun føler at hun må holde blikket på sprøyten eller lene seg framover. Vi ber henne om å legge disse strategiene til side ved å flytte blikket opp mot bildene på veggen foran henne og å sette seg i en mer tilbakelent stilling. Slik unngår hun at sikringsstrategiene holder oppmerksomheten rettet mot det hun frykter skal skje. Ved å gjøre det motsatte av det angsten tilsier, kan hun dessuten kommunisere inn en beskjed til amygdala i den gamle pattedyrhjernen om at situasjonen ikke er farlig. Ord når ikke helt inn til angstsenteret, men 
handling sier mer enn tusen ord - prinsippet er: Show me, don't tell me.

«Prøv å se litt rundt deg. Du har fri vilje til å flytte blikket dit du vil,» instruerer vi. «Ta den tiden du trenger, og tenk på at du har kontroll, og så kan du prøve å løsne grepet litt på sprøyten, hold bare lett på den, uten å klemme hardt.» Nølende gjør Wenche dette, og vi spør igjen hvor sterk angsten er nå. Den stiger kraftig, Wenche kjenner at hun blir svimmel. Hun foretar muskelspenning, og etter hvert er hun nede i 25, pulsen er roligere. Vi tar en pause og diskuterer erfaringene. Wenche sier at hun begynner å bli sliten. Kroppen mobiliserer alt den har av konsentrasjon og krefter, og det er en stor påkjenning. Derfor passer det å slutte dagens økt nå, og vi bruker resten av tiden til å planlegge ukens hjemmeoppgaver.

\section{Akseptere angsten}

Vi begrunner angsttreningen på følgende måte overfor Wenche: Det er en fysiologisk lov som sier at kroppen etter en stund vil venne seg til angsten - det kalles «habituering». Kroppen kan lære seg til å reagere med alarm i bestemte situasjoner, men den kan også lære seg til å slutte å reagere så sterkt. Dette kalles henholdsvis «betinging» og «avbetinging». Wenche vil også gjennom egen erfaring lære seg hvordan hun kan håndtere situasjonene på en bedre måte, og hennes tenkning omkring dem endrer seg. Hun vil danne et nytt bilde av seg selv som en som kan ta på sprøyter, mestre ubehaget og kontrollere situasjonen. Dessuten får hun testet ut gyldigheten av katastrofetankene. Grunnen til at angsttrening har gode resultater, er nettopp at den virker inn på mange ulike nivåer samtidig, fra automatiske, kroppslige betingingsprosesser til endret tenkning og tro på egen mestring.

Under treningen oppfordrer vi Wenche til å åpne seg for angsten, det vil si ikke å tenke på andre ting eller late som om hun er et annet sted. Når angsten kommer, er det viktig at hun går med kroppsreaksjonene, uten å kjempe mot dem eller forsvare seg. Jo mer hun kjemper imot, desto mer aktivert blir kroppen. Dette blir en selvforsterkende, ond sirkel. Hun oppfordres derfor til å prøve å flyte med og akseptere angsten, og så rette oppmerksomheten mot det som skjer. Mottoet er «aksept innover, fokus utover». En øvelse er at Wenche beskriver hva hun gjør etter hvert som hun tar på sprøyten eller snakker om de ulike sprøytedelenes funksjon.

Det er ikke uvanlig at pasienten føler at angsten og ubehaget stiger i begynnelsen av treningen. Det kan da komme en strøm av katastrofetanker og skremmende mentale bilder, noe Wenche også opplever. Dette må ikke ta motet verken fra pasient eller terapeut. Tvert om kan den sterke angsten forstås som et tegn på at treningen begynner å virke. Wenche blir konfrontert med følelser som hun i lang tid har søkt å holde unna, og ved å møte disse på en aksepterende og normaliserende måte vil hun oppnå kontroll over dem.

\section{Målet er nådd}

Etter flere timers trening sier Wenche at hun nå føler seg klar for å sette sprøyten selv. Som en forberedelse ber vi henne om å gå igjennom de konkrete skrittene hun må ta mentalt, som å finne fram sprøyten, ta av plasthetten, finne stikkstedet, sprite det, og så videre. Fire dager senere kommer tekstmeldingen fra Wenche: «Har satt sprøyten selv!!» Hun forteller: «Jeg hadde i bakhodet det dere sa om ikke å la det gå for lang tid. Fredag var tiden inne, det var stille og rolig i huset. Jeg kjente at angsten var innenfor rammene, men hadde den vært 70-80 hadde det vært annerledes. Da jeg tok spissen inn mot huden, tenkte jeg at dette er farlig, men jeg gjorde som dere sa, aksepterte og behandlet angsten i stedet for å benekte den - og sa til meg selv at dette har jeg kontroll over. Etterpå ble jeg sittende og tenke over hva jeg hadde gjort, og så kom jubelbruset i hodet!» En tid senere gjennomfører Wenche blodprøvetaking på laboratoriet på sykehuset. Hun opplever nå å ha realisert de to målene hun har satt seg, både kunne gjøre selvinjeksjon og slik mestre denne delen av det å ha en kronisk revmatisk sykdom, og å kunne ta blodprøver uten sterk angst og uten å grue seg dager på forhånd.

\section{Avslutning}

Forskning viser at resultatene av fobitrening slik vi har beskrevet den, holder seg i mange år (2). Det er imidlertid en forutsetning at Wenche fortsetter å eksponere seg og ikke utvikler nye unngåelsesstrategier. Råd om forebygging av tilbakefall er beskrevet i Berge (11) og Berge og Repål (4). Spesifikk fobi er trolig den psykiske lidelsen som det finnes mest kunnskap om, og som det er mest effektiv og dokumentert behandling for. Det er viktig at helsepersonell både i allmennhelsetjenesten og spesialisthelsetjenesten kan tilby slik behandling eller gi råd om hvordan man kan gjennomføre et selvhjelpsopplegg. IIII

Stor takk til Wenche for verdifulle bidrag til denne artikkelen.
Wenches råd til helsepersonell:

> Ta meg på alvor og respekter angsten min I Ikke prøv å kurere meg for sprøyteskrekken der og da på fem minutter

, Vis aksept for at jeg ikke klarer å sette sprøyten selv

> Ikke reager med en kjekk og grei holdning om at: $\AA$, pytt, dette skal gå så bra, det er ikke farlig; en slik holdning gjør meg reddere og får meg til å føle meg umyndiggjort og enda mer avmektig

, Ved å gjøre enkle ting, for eksempel spørre om du skal si ifra i det du stikker, føler jeg at du har hørt på meg uten at det blir for mye styr rundt det

> Prøv å etablere mest mulig ro i situasjonen > Det er godt å få være i et skjermet rom, fordi jeg bekymrer meg for at andre, for eksempel barn, vil bli skremt hvis jeg roper eller besvimer

Wenches råd til andre som har sprøyteskrekk: > Du er ikke noe dårligere menneske eller pysete fordi du er redd sprøyter

s Ikke undertrykk angsten, men aksepter at den er der

> Ikke unngå å ta medisin, skaff deg heller behandling for angsten

, Fortell om problemet til noen du har tillit til; du trenger støtte og en heiagjeng

I Bruk gradvis angsttrening, planmessig og systematisk, og med små steg i starten

\section{LITTERATUR}

Fjerstad E. Frisk og kronisk syk - et psykologisk perspektiv på kronisk sykdom. Oslo: Gyldendal Akademisk, 2010.

Barlow DH. Anxiety and its disorders. The nature and treatment of anxiety and panic. New York: Guilford Press, 2002.

Hirai M, Clum GA. A meta-analytic study of self-help interventions for anxiety problems. Behavior Therapy 2006; 37: 99-111.


panikk og fobier. Oslo: Aschehoug, 2012.

5. Mohr DC, Cox D, Merluzzi N. Self-injection anxiety training: a treatment for patients unable to self-inject injectable medications. Multiple Sclerosis patients unable

6. Bienvenu OJ, Eaton WW. The epidemiology of blood-injection-injury phobia. Psychological Medicine 1998; 28: 1129-1136.

. Vika M, Raadal M, Skaret E, Kvale G. Dental and medical injections: prevalence of self-reported problems among 18 -yr-old subjects in Norway. European Journal of Oral Sciences 2006; 114: 122-127.

8. Mohr DC, Boudewyn AC, Likosky W, Levine E, Goodkin DE. Injectable medications for the treatment of multiple sclerosis: The influence of expectations and injection anxiety on adherence and ability to self-inject. Annals of Behavioral Medicine 2001; 23: 125-132.

9. Öst LG, Hellström K. Blood-injury-infection phobia. I: Davey GCL, red. Phobias. A handbok of theory, research and treatment. Chichester: John Wiley, 1997: 63-79.

10. Kendler KS, Karkowski LM, Prescott CA. Fears and phobias: reliability and heritability. Psychological Medicine 1999; 29: 539-553.

. Berge T. Spesifikke fobier. I: Berge T, Repål A, red. Håndbok i kognitiv terapi. Oslo: Gyldendal Akademisk, 2008: 132-157.

12. Olatunji BO, Williams NL, SawchukCN, Lohr JM. Disgust, anxiety and fainting symptoms associated with blood-injection-injury fears: a structural model. Anxiety Disorders 2006; 20: 23-41.

3. Ayala ES, Meuret AE, Ritz T. Confrontation with blood and disgust stimuli precipitates respiratory dysregulation in bloood-injection-injury phobia. Biological Psychology 2010; 84: 88-97.

14. LeDoux J. The emotional brain. The mysterious underpinnings of emotional life. New York: Simon \& Schuster, 1996. 